\title{
IMPLEMENTASI ALGORITMA K-MEANS UNTUK PEMILIHAN KERAMIK DAN PELANGGAN POTENSIAL PADA CV. JAYA TUNGGAL KERAMIK
}

\section{Implementation of K-Means Algorithm For Ceramic Selection and Potential Customer at CV. Jaya Tunggal Keramik}

\author{
Yuliana $^{1)}$, Mario Richie ${ }^{2) * d a n ~ H a l i m ~ A g u n g, ~ h a g u n g @ b^{2} \text { damulia.ac.id }}{ }^{3)}$ \\ ${ }^{112)}$ Program Studi Teknik Informatika, Universitas Bunda Mulia
}

\begin{abstract}
CV. Jaya Tunggal Keramik is a company that sale of ceramics. CV. Jaya Tunggal Keramik experienced some problems regarding ceramics and customers such as difficulties in sale ceramics to customers so that some ceramic products accumulate in the warehouse, such as being damaged and ceramic display becomes less good because it is stored too long and difficulty retaining customers because some customers do not want to order ceramic products. Lack of precise decision taken by the management $C V$. Jaya Tunggal Keramik in determining the strategy to supply ceramic and how to make it CV. Jaya Tunggal Keramik is difficult to estimate the stock of ceramic products to be provided and it is difficult to determine which potential customers can be maintained as a regular customer. This research uses $K$ Means algorithm. K-Means algorithm is a partitioning clustering method that separates data into different groups with iterative partitioning. By using this application, users can find out the estimated stock and price of ceramics as well as information about potential customers. Based on ceramic data test results, there are some ceramics that are not in accordance with the predicted results so it can be concluded that the K-Means algorithm on the test inventory data inventory in this study is not fully can provide accurate estimates, this is because the use of the K-Means algorithm is strongly influenced by the cluster center results and the attributes used.
\end{abstract}

Keywords: customer, inventory, $k$-means, clustering

\begin{abstract}
ABSTRAK
CV. Jaya Tunggal Keramik adalah perusahaan yang bergerak dibidang penjualan keramik. CV. Jaya Tunggal Keramik mengalami beberapa permasalahan mengenai keramik dan pelanggan seperti kesulitan memasarkan keramik kepada pelanggan sehingga beberapa produk keramik menumpuk digudang, diantaranya menjadi rusak dan tampilan keramik menjadi kurang bagus karena disimpan terlalu lama serta kesulitan mempertahankan pelanggan dikarenakan beberapa pelanggan tidak ingin melakukan pemesanan produk keramik. Kurangnya tepatnya keputusan yang diambil oleh pihak manajemen CV. Jaya Tunggal Keramik dalam menentukan strategi terhadap persediaan keramik dan cara memasarkannya membuat CV. Jaya Tunggal Keramik kesulitan untuk memperkirakan stok produk keramik yang harus disediakan dan sulit untuk menentukan mana pelanggan yang potensial yang dapat dipertahankan sebagai pelanggan tetap. Penelitian ini menggunakan algoritma $K$-Means. Algoritma K-Means adalah metode clustering secara partitioning yang memisahkan data ke dalam kelompok yang berbeda dengan partitioning secara iteratif. Dengan menggunakan aplikasi ini, pengguna dapat mengetahui perkiraan stok dan harga keramik serta informasi mengenai pelanggan potensial. Berdasarkan hasil pengujian data keramik, terdapat beberapa keramik yang tidak sesuai dengan hasil prediksi sehingga dapat disimpulkan bahwa algoritma $K$-Means pada pengujian data persediaan barang pada penelitian ini tidak sepenuhnya bisa memberikan hasil perkiraan yang tepat, hal ini dikarenakan penggunaan algoritma $K$-Means sangat dipengaruhi oleh hasil pusat cluster dan atribut yang digunakan.
\end{abstract}

Kata Kunci: pelanggan, persediaan barang, $k$-means, clustering 


\section{PENDAHULUAN}

CV. Jaya Tunggal Keramik merupakan salah satu perusahaan yang bergerak dalam bidang penjualan keramik. Dalam menjalankan usahanya, CV. Jaya Tunggal Keramik mengalami beberapa permasalahan mengenai produk keramik dan pelanggan seperti kesulitan memasarkan keramik kepada pelanggan yang mengakibatkan beberapa produk keramik menumpuk digudang, diantaranya menjadi rusak dan tampilan keramik menjadi kurang bagus karena disimpan terlalu lama serta kesulitan mempertahankan pelanggan karena beberapa pelanggan tidak ingin melakukan pemesanan produk keramik. Permasalahan yang terjadi mengakibatkan CV. Jaya Tunggal Keramik mengalami kerugian antara lain penjualan yang mengalami penurunan, target penjualan tidak tercapai, pelanggan kemungkinan beralih kepada perusahaan lain, banyaknya biaya pengeluaran terhadap produk keramik yang kurang diminati pelanggan sehingga mengurangi laba perusahaan.

Kurang tepatnya keputusan yang diambil oleh pihak manajemen CV. Jaya Tunggal Keramik dalam menentukan strategi terhadap persediaan keramik dan cara memasarkannya serta masih menggunakan pencatatan secara manual membuat CV. Jaya Tunggal Keramik kesulitan untuk memperkirakan stok produk keramik yang harus disediakan dan sulit untuk menentukan mana pelanggan yang potensial yang dapat dipertahankan sebagai pelanggan tetap. Data - data manual yang ada tidak dimanfaatkan oleh CV. Jaya Tunggal Keramik secara optimal untuk memperoleh informasi dikarenakan kesulitan mencari data - data yang ada dan memakan waktu yang lama karena harus dicari satu per satu.

Berdasarkan permasalahan yang terjadi di CV. Jaya Tunggal Keramik maka dalam penelitian ini, peneliti mengimplementasikan algoritma $K$-Means untuk dapat memperkirakan stok keramik yang harus disiapkan untuk penjualan keramik serta dapat diperoleh informasi mengenai data pelanggan yang potensial.

Algoritma K-Means dapat digunakan untuk menyelesaikan beberapa permasalahan yang ada, seperti pada penelitian terdahulu yang dilakukan oleh peneliti sebelumnya dengan mengimplementasikan algoritma $K$-Means clustering untuk menentukan strategi marketing President University [4]. Pada penelitiannya, algoritma K-Means sukses diimplementasikan karena dapat diperoleh strategi promosi yang dapat dilakukan oleh pihak marketing President University untuk memperoleh calon mahasiswa baru.

Algoritma K-Means juga dapat digunakan untuk clustering produk online shop dalam penentuan stok barang [3] seperti yang dijelaskan dalam penelitian terdahulu mengenai algoritma K-Means dimana dihasilkan beberapa produk yang paling diminati untuk jumlah stok terbanyak dan produk yang kurang diminati untuk jumlah stok sedikit.

Algoritma K-Means juga digunakan untuk memberikan rekomendasi dosen tetap berdasarkan penilaian dosen [4] seperti yang dijelaskan dalam penelitian terdahulu mengenai algoritma K-Means dimana keberhasilan algoritma dalam memberikan rekomendasi dosen tetap sebesar $55.75 \%$.

\section{TINJAUAN PUSTAKA}

\section{Clustering}

Pada dasarnya clustering merupakan suatu metode untuk mencari dan mengelompokkan data yang memiliki kemiripan karakteristik (similarity) antara satu data dengan data yang lain. Clustering merupakan salah satu metode data mining yang bersifat tanpa arahan (unsupervised), maksudnya metode ini diterapkan tanpa adanya latihan (training) dan tanpa ada guru (teacher) serta tidak memerlukan target output. Dalam data mining ada dua jenis metode clustering yang digunakan dalam pengelompokan data, yaitu hierarchical clustering dan nonhierarchical clustering [6]. 
Clustering lebih ke arah pengelompokan record, pengamatan, atau kasus dalam kelas yang memiliki kemiripan. Sebuah cluster adalah kumpulan record yang memiliki kemiripan satu dengan yang lain dan memiliki ketidak miripan dengan record-record dalam cluster yang lain [2].

Hierarchical clustering adalah suatu metode pengelompokan data yang dimulai dengan mengelompokkan dua atau lebih objek yang memiliki kesamaan paling dekat. Kemudian proses diteruskan ke objek lain yang memiliki kedekatan kedua. Demikian seterusnya sehingga cluster akan membentuk semacam pohon dimana ada hierarki (tingkatan) yang jelas antar objek, dari yang paling mirip sampai yang paling tidak mirip. Secara logika semua objek pada akhirnya hanya akan membentuk sebuah cluster. Dendogram biasanya digunakan untuk membantu memperjelas proses hierarki tersebut [7]. Berbeda dengan metode hierarchical clustering, metode nonhierarchical clustering justru dimulai dengan menentukan terlebih dahulu jumlah cluster yang diinginkan (dua cluster, tiga cluster, atau lain sebagainya). Setelah jumlah cluster diketahui, baru proses cluster dilakukan tanpa mengikuti proses hierarki. Metode ini biasa disebut dengan $K$ Means Clustering [7].

\section{Algoritma $K$-Means}

K-Means merupakan metode clustering secara partitioning yang memisahkan data ke dalam kelompok yang berbeda dengan partitioning secara iteratif, K-Means mampu meminimalkan rata-rata jarak setiap data ke cluster [1].

Proses pengelompokan data secara umum ke dalam cluster tertuang dalam algoritma clustering, dalam hal ini digunakan algoritma K-Means. Algoritma $K$-Means mendasari metode operasinya berdasarkan namanya yaitu 'mean' atau rerata. Dimana akan dilakukan pengamatan ke dalam kelompok $\mathrm{k}$, dimana $\mathrm{k}$ diberikan sebagai parameter masukan. Kemudian dilakukan pengamatan pola untuk setiap kelompok berdasarkan kedekatan pada rerata jarak cluster yang adalah titik tengah, selanjutnya titik pusat atau centroid akan dikalkulasi ulang dan proses dimulai kembali. K-Means adalah teknik yang dikategorikan greedy, komputasi dilakukan dengan teknik yang efisien, menjadi salah satu algoritma clustering yang paling banyak digunakan untuk klasterisasi. Pada algoritma clustering, fokus ditujukan pada penentuan jumlah cluster atau k. Jumlah cluster yang ingin dibentuk ini akan digunakan sebagai masukan bagi algoritma. Pada dasarnya algoritma tidak mampu menentukan jumlah cluster dan ini bergantung sepenuhnya pada pengguna untuk mengidentifikasi terlebih dahulu jumlah cluster yang diinginkan. Tidak mudah menentukan banyak cluster, dan ini adalah strategi yang dipilih dengan asumsi bahkan pertimbangan yang sifatnya intuitif [8].

Langkah-langkah melakukan clustering dengan algoritma K-Means adalah [6] Langkah 1, Pilih jumlah cluster k. Langkah 2, Inisialisasi k pusat cluster ini bisa dilakukan dengan berbagai cara. Namun yang paling sering dilakukan adalah dengan cara random. Pusat-pusat cluster diberi nilai awal dengan angka-angka random. Langkah 3, Alokasikan semua data / objek ke cluster terdekat. Kedekatan dua objek ditentukan berdasarkan jarak kedua objek tersebut. Demikian juga kedekatan suatu data ke cluster tertentu ditentukan jarak antara data dengan pusat cluster. Dalam tahap ini perlu dihitung jarak tiap data ke tiap pusat cluster. Jarak paling dekat antara satu data dengan satu cluster tertentu akan menentukan suatu data masuk dalam cluster mana. Untuk menghitung jarak semua data ke setiap titik pusat cluster dapat menggunakan teori jarak Euclidean yang dirumuskan pada rumus (1).

$D(i, j)=\sqrt{\left(X_{1 i}-X_{1 j}\right)^{2}+\left(X_{2 i}-X_{2 j}\right)^{2}+\ldots+\left(X_{k i}-X_{k i}\right)^{2}}$ 
dimana $D(i, j)=$ Jarak data ke $i$ ke pusat cluster $j, X_{k i}=$ Data ke $i$ pada atribut data ke $k$ dan $X_{k j}=$ Titik pusat ke $j$ pada atribut ke $k$

Langkah 4, Hitung kembali pusat cluster dengan keanggotaan cluster yang sekarang. Pusat cluster adalah rata-rata dari semua data / objek dalam cluster tertentu. Jika dikehendaki bisa juga menggunakan median dari cluster tersebut. Jadi rata-rata (mean) bukan satu-satunya ukuran yang bisa dipakai. Langkah 5, Tugaskan lagi setiap objek memakai pusat cluster yang baru. Jika pusat cluster tidak berubah lagi maka proses clustering selesai. Atau, kembali ke langkah c sampai pusat cluster tidak berubah lagi.

\section{METODE PENELITIAN}

Data - data yang digunakan dalam penelitian ini adalah data bulan November 2017. Dalam penelitian ini, hanya digunakan beberapa atribut data seperti nama keramik, quantity penjualan, harga untuk data keramik dan nama pelanggan, jumlah pembelian, total transaksi untuk data pelanggan. Pengolahan data dilakukan dengan mengelompokkan berdasarkan kemiripan karakteristik dari setiap data. Berikut ini adalah beberapa data keramik pada bulan November 2017.

Tabel 1 Data Keramik

\begin{tabular}{|l|l|c|c|}
\hline No. & Nama Keramik & $\begin{array}{l}\text { Quantity } \\
\text { Penjualan }\end{array}$ & Harga \\
\hline 1 & Maluku Wood & 1000 & 52.000 \\
\hline 2 & Gianyar & 500 & 52.000 \\
\hline 3 & Singaraja & 650 & 52.000 \\
\hline 4 & Arish Hijau & 300 & 45.000 \\
\hline 5 & Rosetta Beige & 150 & 45.000 \\
\hline 6 & Ketty Yellowish & 300 & 50.000 \\
\hline 7 & Matrix Beige & 200 & 47.000 \\
\hline
\end{tabular}

Untuk melakukan pengelompokan data-data keramik menjadi beberapa cluster dilakukan dengan langkah - langkah yaitu Langkah 1, Mengelompokkan data keramik menjadi dua cluster.

Langkah 2, Menentukan titik pusat awal dari setiap cluster berdasarkan

\begin{tabular}{|l|l|l|l|}
\hline 8 & Fuzy Grey & 600 & 50.000 \\
\hline 9 & Orion Grey & 350 & 43.000 \\
\hline 10 & Bawean Grey & 200 & 43.000 \\
\hline
\end{tabular}

Untuk melakukan pengelompokan data-data keramik menjadi beberapa cluster dilakukan dengan langkah - langkah yaitu Langkah 1, Mengelompokkan data keramik menjadi dua cluster.

Langkah 2, Menentukan titik pusat awal dari setiap cluster berdasarkan quantity penjualan keramik tertinggi, quantity penjualan keramik terendah, harga tertinggi dan harga terendah

Tabel 2 Tabel Awal Clustering

\begin{tabular}{|l|c|c|}
\hline & Quantity Penjualan & Harga \\
\hline C1 & 1000 & 52000 \\
\hline C2 & 150 & 43000 \\
\hline
\end{tabular}

Langkah 3, Menempatkan setiap data pada cluster. Dalam penelitian ini digunakan metode hard K-Means untuk mengalokasikan setiap data ke dalam suatu cluster, sehingga data akan dimasukkan dalam suatu cluster yang memiliki jarak paling dekat dengan titik pusat dari setiap cluster. Untuk mengetahui cluster mana yang paling dekat dengan data, maka perlu dihitung jarak setiap data dengan titik pusat setiap cluster. Hasil perhitungan jarak dari data keramik pertama ke pusat cluster pertama adalah $D(1,1)=0$

Jarak data keramik pertama dengan pusat cluster kedua adalah $D(1,2)=9040$

Berdasarkan hasil kedua perhitungan di atas, terlihat bahwa jarak data keramik pertama yang paling dekat adalah dengan cluster 1, sehingga data keramik pertama dimasukkan ke dalam cluster 1 yang ditandai dengan angka 1 pada $\mathrm{C} 1$. Hasil perhitungan selengkapnya setelah diimplementasikan pada program terlihat pada Tabel 3. quantity penjualan keramik tertinggi, quantity penjualan keramik terendah, harga tertinggi dan harga terendah

Tabel 2 Tabel Awal Clustering

\begin{tabular}{|l|c|c|}
\hline & Quantity Penjualan & Harga \\
\hline C1 & 1000 & 52000 \\
\hline C2 & 150 & 43000 \\
\hline
\end{tabular}


Langkah 3, Menempatkan setiap data pada cluster. Dalam penelitian ini digunakan metode hard K-Means untuk mengalokasikan setiap data ke dalam suatu cluster, sehingga data akan dimasukkan dalam suatu cluster yang memiliki jarak paling dekat dengan titik pusat dari setiap cluster. Untuk mengetahui cluster mana yang paling dekat dengan data, maka perlu dihitung jarak setiap data dengan titik pusat setiap cluster. Hasil perhitungan jarak dari data keramik pertama ke pusat cluster pertama adalah $D(1,1)=0$

Jarak data keramik pertama dengan pusat cluster kedua adalah $D(1,2)=9040$

Berdasarkan hasil kedua perhitungan di atas, terlihat bahwa jarak data keramik pertama yang paling dekat adalah dengan cluster 1, sehingga data keramik pertama dimasukkan ke dalam cluster 1 yang ditandai dengan angka 1 pada $\mathrm{C} 1$. Hasil perhitungan selengkapnya setelah diimplementasikan pada program terlihat pada Tabel 3 .

Tabel 3 Perhitungan Jarak Antara Pusat Cluster Dengan Data Keramik

\begin{tabular}{|c|c|c|c|c|c|c|c|}
\hline $\begin{array}{l}\mathrm{N} \\
\mathrm{O}\end{array}$ & $\begin{array}{c}\text { Nama } \\
\text { Kera } \\
\text { mik }\end{array}$ & $\begin{array}{l}\text { Quant } \\
\text { ity } \\
\text { Penju } \\
\text { alan } \\
\end{array}$ & $\begin{array}{l}\text { Har } \\
\text { ga }\end{array}$ & $\begin{array}{c}\text { Centroid } \\
1 \\
(1000 \\
52000)\end{array}$ & $\begin{array}{l}\text { Centr } \\
\text { oid } 2 \\
(150,4 \\
3000) \\
\end{array}$ & $\begin{array}{l}\mathrm{C} \\
1\end{array}$ & $\begin{array}{l}\mathrm{C} \\
2\end{array}$ \\
\hline 1 & $\begin{array}{c}\text { MALU } \\
\text { KU } \\
\text { WOO } \\
\text { D }\end{array}$ & 1000 & $\begin{array}{c}520 \\
00\end{array}$ & 0 & $\begin{array}{c}9040 . \\
04977 \\
8624\end{array}$ & 1 & 0 \\
\hline 2 & $\begin{array}{l}\text { GIAN } \\
\text { YAR }\end{array}$ & 500 & $\begin{array}{c}520 \\
00\end{array}$ & 500 & $\begin{array}{l}9006 . \\
80298 \\
44113\end{array}$ & 1 & 0 \\
\hline 3 & $\begin{array}{c}\text { SING } \\
\text { ARAJ } \\
\text { A }\end{array}$ & 650 & $\begin{array}{c}520 \\
00\end{array}$ & 350 & $\begin{array}{c}9013 . \\
87818 \\
866\end{array}$ & 1 & 0 \\
\hline 4 & $\begin{array}{c}\text { ARIS } \\
\text { H } \\
\text { HIJAU }\end{array}$ & 300 & $\begin{array}{c}450 \\
00\end{array}$ & $\begin{array}{c}7034.91 \\
2934784 \\
6\end{array}$ & $\begin{array}{l}2005 . \\
61711 \\
20132\end{array}$ & 0 & 1 \\
\hline 5 & $\begin{array}{c}\text { ROSE } \\
\text { TTA } \\
\text { BEIG } \\
\text { E }\end{array}$ & 150 & $\begin{array}{c}450 \\
00\end{array}$ & $\begin{array}{l}7051.41 \\
8297052\end{array}$ & 2000 & 0 & 1 \\
\hline 6 & $\begin{array}{c}\text { KETT } \\
\text { Y } \\
\text { YELL } \\
\text { OWIS } \\
\text { H }\end{array}$ & 300 & $\begin{array}{c}500 \\
00\end{array}$ & $\begin{array}{c}2118.96 \\
2010041 \\
7\end{array}$ & $\begin{array}{c}7001 . \\
60695 \\
8406\end{array}$ & 1 & 0 \\
\hline 7 & $\begin{array}{c}\text { MATR } \\
\text { IX } \\
\text { BEIG } \\
\text { E }\end{array}$ & 200 & $\begin{array}{c}470 \\
00\end{array}$ & $\begin{array}{c}5063.59 \\
5560468 \\
9\end{array}$ & $\begin{array}{l}4000 . \\
31248 \\
77939\end{array}$ & 0 & 1 \\
\hline 8 & $\begin{array}{l}\text { FUZY } \\
\text { GREY }\end{array}$ & 600 & $\begin{array}{c}500 \\
00\end{array}$ & $\begin{array}{c}2039.60 \\
7805437 \\
1\end{array}$ & $\begin{array}{l}7014 . \\
44937 \\
25452 \\
\end{array}$ & 1 & 0 \\
\hline 9 & $\begin{array}{c}\text { ORIO } \\
N \\
\text { GREY }\end{array}$ & 350 & $\begin{array}{c}430 \\
00\end{array}$ & $\begin{array}{c}9023.44 \\
1693722\end{array}$ & 200 & 0 & 1 \\
\hline $\begin{array}{l}1 \\
0\end{array}$ & $\begin{array}{l}\text { BAW } \\
\text { EAN } \\
\text { GREY }\end{array}$ & 200 & $\begin{array}{c}430 \\
00\end{array}$ & $\begin{array}{c}9035.48 \\
5598461 \\
2\end{array}$ & 50 & 0 & 1 \\
\hline
\end{tabular}

Langkah 4, Setelah semua data ditempat ke dalam cluster yang terdekat, kemudian dihitung kembali pusat cluster yang baru berdasarkan rata-rata anggota yang ada pada cluster dengan cara membagi jumlah quantity penjualan dan harga dengan jumlah data pada masing - masing cluster.

Jumlah quantity penjualan yang ada pada $\mathrm{C} 1$ adalah 3.050 , banyaknya data pada $\mathrm{C} 1$ adalah 5 sehingga didapatkan hasil pusat cluster baru sebesar 610 untuk quantity penjualan dan 51.200 untuk harga. Hasil perhitungan selengkapnya untuk pusat cluster baru terlihat pada Tabel 4 .

\section{Tabel 4 Tabel Pusat Cluster Baru}

\begin{tabular}{|l|c|c|}
\hline & Quantity Penjualan & Harga \\
\hline C1 & 610 & 51200 \\
\hline C2 & 240 & 44600 \\
\hline
\end{tabular}

Langkah 5, Setelah didapatkan titik pusat yang baru dari setiap cluster, dilakukan perhitungan kembali jarak setiap data dengan titik pusat setiap cluster hingga titik pusat dari setiap cluster tidak berubah lagi dan tidak ada lagi data yang berpindah dari satu cluster ke cluster yang lain.

Dalam penelitian ini, iterasi clustering data keramik terjadi sebanyak 2 kali iterasi. Pada iterasi ke-2, titik pusat dari setiap cluster sudah tidak berubah dan tidak ada lagi data yang berpindah dari satu cluster ke cluster yang lain sehingga didapatkan hasil perkiraan stok keramik dan harga keramik pada program ditunjukkan pada Tabel 5.

Tabel 5 Hasil Perkiraan Stok dan Harga Keramik

\begin{tabular}{|c|c|c|c|c|c|}
\hline No & Nama Keramik & $\begin{array}{c}\text { Qty } \\
\text { Pen- } \\
\text { jualan }\end{array}$ & Harga & $\begin{array}{c}\text { Qty } \\
\text { Stok } \\
\text { Predik } \\
\text { si }\end{array}$ & $\begin{array}{c}\text { Harga } \\
\text { Predik } \\
\text { si }\end{array}$ \\
\hline 1 & $\begin{array}{c}\text { MALUKU } \\
\text { WOOD }\end{array}$ & 1000 & 52000 & 610 & 51200 \\
\hline 2 & GIANYAR & 500 & 52000 & 610 & 51200 \\
\hline 3 & SINGARAJA & 650 & 52000 & 610 & 51200 \\
\hline 4 & ARISH HIJAU & 300 & 45000 & 240 & 44600 \\
\hline 5 & $\begin{array}{c}\text { ROSETTA } \\
\text { BEIGE }\end{array}$ & 150 & 45000 & 240 & 44600 \\
\hline 6 & $\begin{array}{c}\text { KETTY } \\
\text { YELLOWISH }\end{array}$ & 300 & 50000 & 610 & 51200 \\
\hline 7 & MATRIX BEIGE & 200 & 47000 & 240 & 44600 \\
\hline 8 & FUZY GREY & 600 & 50000 & 610 & 51200 \\
\hline 9 & ORION GREY & 350 & 43000 & 240 & 44600 \\
\hline 10 & BAWEAN GREY & 200 & 43000 & 240 & 44600 \\
\hline
\end{tabular}

Langkah 6, Hasil perkiraan stok dan harga diperoleh dari pusat cluster terakhir. Apabila data keramik berada pada C1 maka stok dan harga prediksi akan diambil dari pusat cluster $\mathrm{C} 1$, sebaliknya apabila data keramik berada pada C2 maka 
stok dan harga prediksi akan diambil dari pusat cluster $\mathrm{C} 2$.

Selanjutnya, untuk melakukan pengelompokan data-data pelanggan menjadi beberapa cluster dilakukan langkah - langkah yang sama seperti pengelompokan data keramik. Untuk data pelanggan akan menghasilkan informasi pelanggan yang potensial. Syarat pelanggan potensial di CV. Jaya Tunggal Keramik adalah pelanggan yang mempunyai transaksi sepuluh juta rupiah dan di atas sepuluh juta rupiah serta sering melakukan pembelian keramik. Hasil output data pelanggan pada bulan November 2017 dapat dilihat pada Tabel 6 .

Tabel 6 Hasil Output Data Pelanggan

\begin{tabular}{|c|c|c|c|c|}
\hline No & $\begin{array}{c}\text { Nama } \\
\text { Pelanggan }\end{array}$ & $\begin{array}{c}\text { Jumlah } \\
\text { Pembelian }\end{array}$ & $\begin{array}{c}\text { Total } \\
\text { Transaksi }\end{array}$ & Keterangan \\
\hline 1 & $\begin{array}{l}\text { Chandra } \\
\text { Agung } \\
\text { Perkasa }\end{array}$ & 1 & $4.500 .000,00$ & $\begin{array}{c}\text { tidak } \\
\text { potensial }\end{array}$ \\
\hline 2 & Cemerlang & 1 & $6.525 .000,00$ & $\begin{array}{c}\text { tidak } \\
\text { potensial }\end{array}$ \\
\hline 3 & $\begin{array}{l}\text { Guna } \\
\text { Bangunan }\end{array}$ & 1 & $3.525 .000,00$ & $\begin{array}{c}\text { tidak } \\
\text { potensial }\end{array}$ \\
\hline 4 & $\begin{array}{l}\text { Klasit } \\
\text { Abadi }\end{array}$ & 2 & $4.700 .000,00$ & $\begin{array}{c}\text { tidak } \\
\text { potensial }\end{array}$ \\
\hline 5 & Sinar Baru & 1 & $4.350 .000,00$ & $\begin{array}{c}\text { tidak } \\
\text { potensial }\end{array}$ \\
\hline 6 & $\begin{array}{l}\text { Adika } \\
\text { Sentosa } \\
\end{array}$ & 1 & $10.400 .000,00$ & $\begin{array}{c}\text { tidak } \\
\text { potensial }\end{array}$ \\
\hline 7 & $\begin{array}{l}\text { Sinar } \\
\text { Remaja }\end{array}$ & 1 & $4.420 .000,00$ & $\begin{array}{c}\text { tidak } \\
\text { potensial }\end{array}$ \\
\hline 8 & $\begin{array}{l}\text { Omega } \\
\text { Ceramice }\end{array}$ & 1 & $5.000 .000,00$ & $\begin{array}{c}\text { tidak } \\
\text { potensial }\end{array}$ \\
\hline 9 & $\begin{array}{l}\text { Bintang } \\
\text { Jaya }\end{array}$ & 1 & $870.000,00$ & $\begin{array}{c}\text { tidak } \\
\text { potensial }\end{array}$ \\
\hline 10 & Laguna & 3 & $15.000 .000,00$ & potensial \\
\hline
\end{tabular}

\section{HASIL DAN PEMBAHASAN}

Berdasarkan hasil pengujian 34 data keramik yang dilakukan antara data prediksi bulan November dengan bulan Desember 2017 terlihat bahwa hanya 6 keramik yang sesuai atau mendekati perkiraan dengan stok bulan Desember yang sedang berjalan. Sedangkan 23 data keramik lainnya tidak sesuai dengan hasil prediksi dan 5 buah keramik tidak distok dengan alasan barang tersebut kurang laku. Untuk hasil data pelanggan seperti yang ditampilkan pada Tabel 6, terlihat bahwa pelanggan yang potensial adalah Laguna karena sering melakukan pembelian sebanyak tiga kali dengan total transaksi terbesar yaitu lima belas juta rupiah. Hasil data output sesuai dengan syarat ketentuan di CV. Jaya Tunggal keramik. Hasil pengujian dengan menggunakan 34 data keramik setelah implementasi pada program dapat dilihat pada Tabel 7

Tabel 7 Hasil Pengujian Data Keramik Pada Program

\begin{tabular}{|c|c|c|c|c|c|c|c|}
\hline $\begin{array}{l}\mathrm{N} \\
\mathrm{O}\end{array}$ & $\begin{array}{c}\text { Nama } \\
\text { Keramik }\end{array}$ & $\begin{array}{l}\text { Qty } \\
\text { Penju } \\
\text { alan }\end{array}$ & $\begin{array}{c}\text { Har } \\
\text { ga }\end{array}$ & $\begin{array}{c}\text { Qty } \\
\text { Pred } \\
\text { iksi }\end{array}$ & $\begin{array}{c}\text { Harg } \\
\text { a } \\
\text { Pred } \\
\text { iksi }\end{array}$ & $\begin{array}{l}\text { Stok } \\
\text { Dese } \\
\text { mber }\end{array}$ & $\begin{array}{c}\text { Ketera } \\
\text { ngan }\end{array}$ \\
\hline 1 & $\begin{array}{l}\text { MALUK } \\
U \\
\text { WOOD }\end{array}$ & 1000 & $\begin{array}{c}520 \\
00 \\
\end{array}$ & 297 & $\begin{array}{c}51.7 \\
35 \\
\end{array}$ & 1500 & $\begin{array}{l}\text { Tidak } \\
\text { sesuai }\end{array}$ \\
\hline 2 & $\begin{array}{l}\text { BROM } \\
\mathrm{O} \\
\text { BROW } \\
\mathrm{N}\end{array}$ & 250 & $\begin{array}{c}520 \\
00\end{array}$ & 297 & $\begin{array}{c}51.7 \\
35\end{array}$ & 150 & $\begin{array}{l}\text { Tidak } \\
\text { sesuai }\end{array}$ \\
\hline 3 & $\begin{array}{l}\text { BROM } \\
\text { O } \\
\text { GREY }\end{array}$ & 150 & $\begin{array}{c}520 \\
00 \\
\end{array}$ & 297 & $\begin{array}{c}51.7 \\
35 \\
\end{array}$ & 290 & sesuai \\
\hline 4 & $\begin{array}{l}\text { KRAKA } \\
\text { TAU } \\
\text { BLACK }\end{array}$ & 200 & $\begin{array}{c}520 \\
00\end{array}$ & 297 & $\begin{array}{c}51.7 \\
35\end{array}$ & 100 & $\begin{array}{l}\text { Tidak } \\
\text { sesuai }\end{array}$ \\
\hline 5 & $\begin{array}{l}\text { KRAKA } \\
\text { TAU } \\
\text { GREY }\end{array}$ & 200 & $\begin{array}{c}520 \\
00\end{array}$ & 297 & $\begin{array}{c}51.7 \\
35\end{array}$ & 100 & $\begin{array}{l}\text { Tidak } \\
\text { sesuai }\end{array}$ \\
\hline 6 & $\begin{array}{l}\text { MATAR } \\
\text { AM } \\
\text { WOOD }\end{array}$ & 150 & $\begin{array}{c}520 \\
00\end{array}$ & 297 & $\begin{array}{c}51.7 \\
35\end{array}$ & 100 & $\begin{array}{l}\text { Tidak } \\
\text { sesuai }\end{array}$ \\
\hline 7 & $\begin{array}{l}\text { MAHAK } \\
\text { AM }\end{array}$ & 300 & $\begin{array}{c}520 \\
00\end{array}$ & 297 & $\begin{array}{c}51.7 \\
35\end{array}$ & 400 & $\begin{array}{c}\text { Tidak } \\
\text { sesuai }\end{array}$ \\
\hline 8 & $\begin{array}{l}\text { JAVA } \\
\text { WOOD }\end{array}$ & 150 & $\begin{array}{c}520 \\
00\end{array}$ & 297 & $\begin{array}{c}51.7 \\
35\end{array}$ & 75 & $\begin{array}{l}\text { Tidak } \\
\text { sesuai }\end{array}$ \\
\hline 9 & $\begin{array}{l}\text { GIANY } \\
\text { AR }\end{array}$ & 500 & $\begin{array}{c}520 \\
00 \\
\end{array}$ & 297 & $\begin{array}{c}51.7 \\
35\end{array}$ & 50 & $\begin{array}{c}\text { Tidak } \\
\text { sesuai }\end{array}$ \\
\hline $\begin{array}{l}1 \\
0\end{array}$ & $\begin{array}{l}\text { SINGA } \\
\text { RAJA }\end{array}$ & 650 & $\begin{array}{c}520 \\
00\end{array}$ & 297 & $\begin{array}{c}51.7 \\
35\end{array}$ & 300 & sesuai \\
\hline $\begin{array}{l}1 \\
1\end{array}$ & $\begin{array}{l}\text { HOUST } \\
\text { ON } \\
\text { BROW } \\
N\end{array}$ & 100 & $\begin{array}{c}520 \\
00\end{array}$ & 297 & $\begin{array}{c}51.7 \\
35\end{array}$ & 50 & $\begin{array}{l}\text { Tidak } \\
\text { sesuai }\end{array}$ \\
\hline $\begin{array}{l}1 \\
2\end{array}$ & $\begin{array}{l}\text { ARISH } \\
\text { HIJAU }\end{array}$ & 300 & $\begin{array}{c}450 \\
00\end{array}$ & 175 & $\begin{array}{c}44.9 \\
41\end{array}$ & 180 & sesuai \\
\hline $\begin{array}{l}1 \\
3\end{array}$ & ARISH & 300 & $\begin{array}{c}450 \\
00\end{array}$ & 175 & $\begin{array}{c}44.9 \\
41\end{array}$ & 700 & $\begin{array}{l}\text { Tidak } \\
\text { sesuai }\end{array}$ \\
\hline $\begin{array}{l}1 \\
4\end{array}$ & $\begin{array}{l}\text { ARISH } \\
\text { ABU }\end{array}$ & 125 & $\begin{array}{c}450 \\
00\end{array}$ & 175 & $\begin{array}{c}44.9 \\
41\end{array}$ & 800 & $\begin{array}{l}\text { Tidak } \\
\text { sesuai }\end{array}$ \\
\hline $\begin{array}{l}1 \\
5 \\
\end{array}$ & $\begin{array}{l}\text { ROSET } \\
\text { TA } \\
\text { BEIGE }\end{array}$ & 150 & $\begin{array}{c}450 \\
00 \\
\end{array}$ & 175 & $\begin{array}{c}44.9 \\
41 \\
\end{array}$ & 0 & $\begin{array}{l}\text { Tidak } \\
\text { sesuai }\end{array}$ \\
\hline $\begin{array}{l}3 \\
6\end{array}$ & ROSET & 150 & $\begin{array}{c}0 \\
450 \\
00\end{array}$ & 175 & $\begin{array}{c}44.9 \\
41\end{array}$ & 125 & $\begin{array}{l}\text { Tidak } \\
\text { sesuai }\end{array}$ \\
\hline $\begin{array}{l}1 \\
7 \\
\end{array}$ & $\begin{array}{l}\text { KETTY } \\
\text { YELLO } \\
\text { WISH }\end{array}$ & 300 & $\begin{array}{c}500 \\
00\end{array}$ & 297 & $\begin{array}{c}51.7 \\
35\end{array}$ & 0 & $\begin{array}{l}\text { Tidak } \\
\text { sesuai }\end{array}$ \\
\hline $\begin{array}{l}1 \\
8\end{array}$ & $\begin{array}{l}\text { KETTY } \\
\text { BLUISH }\end{array}$ & 125 & $\begin{array}{c}500 \\
00\end{array}$ & 297 & $\begin{array}{c}51.7 \\
35\end{array}$ & 295 & sesuai \\
\hline 1 & JENIFE & 150 & 500 & 297 & $\begin{array}{c}51.7 \\
35\end{array}$ & 500 & $\begin{array}{l}\text { Tidak } \\
\text { Sesuai }\end{array}$ \\
\hline $\begin{array}{l}2 \\
0\end{array}$ & $\begin{array}{l}\text { BRIAN } \\
\text { GREEN }\end{array}$ & 100 & $\begin{array}{c}500 \\
00\end{array}$ & 297 & $\begin{array}{c}51.7 \\
35\end{array}$ & 100 & $\begin{array}{l}\text { Tidak } \\
\text { sesuai }\end{array}$ \\
\hline $\begin{array}{l}2 \\
1\end{array}$ & $\begin{array}{l}\text { MATRI } \\
X \\
\text { BEIGE }\end{array}$ & 200 & $\begin{array}{c}470 \\
00\end{array}$ & 175 & $\begin{array}{c}44.9 \\
41\end{array}$ & 100 & $\begin{array}{l}\text { Tidak } \\
\text { sesuai }\end{array}$ \\
\hline $\begin{array}{l}1 \\
2 \\
2\end{array}$ & $\begin{array}{l}\text { MATRI } \\
\text { X BLUE }\end{array}$ & 200 & $\begin{array}{c}070 \\
00\end{array}$ & 175 & $\begin{array}{c}44.9 \\
41\end{array}$ & 100 & $\begin{array}{l}\text { Tidak } \\
\text { sesuai }\end{array}$ \\
\hline $\begin{array}{l}2 \\
3\end{array}$ & $\begin{array}{l}\text { MATRI } \\
X \\
\text { GREEN }\end{array}$ & 100 & $\begin{array}{c}470 \\
00\end{array}$ & 175 & $\begin{array}{c}44.9 \\
41\end{array}$ & 50 & $\begin{array}{l}\text { Tidak } \\
\text { sesuai }\end{array}$ \\
\hline $\begin{array}{l}2 \\
4\end{array}$ & $\begin{array}{l}\text { VENUS } \\
\text { BEIGE }\end{array}$ & 100 & $\begin{array}{c}470 \\
00\end{array}$ & 175 & $\begin{array}{c}44.9 \\
41\end{array}$ & 0 & $\begin{array}{l}\text { Tidak } \\
\text { sesuai }\end{array}$ \\
\hline $\begin{array}{l}2 \\
5\end{array}$ & $\begin{array}{l}\text { VENUS } \\
\text { BLUE }\end{array}$ & 125 & $\begin{array}{c}470 \\
00\end{array}$ & 175 & $\begin{array}{c}44.9 \\
41\end{array}$ & 250 & $\begin{array}{l}\text { Tidak } \\
\text { sesuai }\end{array}$ \\
\hline $\begin{array}{l}2 \\
6\end{array}$ & $\begin{array}{l}\text { FUZY } \\
\text { GREY }\end{array}$ & 600 & $\begin{array}{c}500 \\
00\end{array}$ & 297 & $\begin{array}{c}51.7 \\
35\end{array}$ & 150 & $\begin{array}{l}\text { Tidak } \\
\text { sesuai }\end{array}$ \\
\hline $\begin{array}{l}2 \\
7\end{array}$ & $\begin{array}{l}\text { SOPHI } \\
\text { E } \\
\text { BEIGE }\end{array}$ & 120 & $\begin{array}{c}575 \\
00\end{array}$ & 297 & $\begin{array}{c}51.7 \\
35\end{array}$ & 175 & $\begin{array}{l}\text { Tidak } \\
\text { sesuai }\end{array}$ \\
\hline $\begin{array}{l}2 \\
8\end{array}$ & $\begin{array}{l}\text { ORION } \\
\text { GREY }\end{array}$ & 350 & $\begin{array}{c}430 \\
00\end{array}$ & 175 & $\begin{array}{c}44.9 \\
41\end{array}$ & 0 & $\begin{array}{l}\text { Tidak } \\
\text { sesuai }\end{array}$ \\
\hline 2 & ORION & 150 & 430 & 175 & $\begin{array}{c}44.9 \\
41\end{array}$ & 0 & Tidak \\
\hline $\begin{array}{l}3 \\
0\end{array}$ & $\begin{array}{l}\text { BEIGE } \\
\text { BAWEA } \\
\mathrm{N} \\
\text { GREY }\end{array}$ & 200 & $\begin{array}{c}430 \\
00\end{array}$ & 175 & $\begin{array}{c}44.9 \\
41\end{array}$ & 50 & $\begin{array}{c}\text { sesual } \\
\text { Tidak } \\
\text { sesuai }\end{array}$ \\
\hline
\end{tabular}




\begin{tabular}{|c|c|c|c|c|c|c|c|}
\hline $\begin{array}{l}3 \\
1 \\
\end{array}$ & $\begin{array}{l}\text { AGACI } \\
\text { A } \\
\text { GREY }\end{array}$ & 100 & $\begin{array}{c}430 \\
00\end{array}$ & 175 & $\begin{array}{c}44.9 \\
41\end{array}$ & 174 & sesuai \\
\hline $\begin{array}{l}3 \\
2 \\
\end{array}$ & $\begin{array}{l}\text { SAHAR } \\
\text { A } \\
\text { BEIGE }\end{array}$ & 120 & $\begin{array}{c}450 \\
00\end{array}$ & 175 & $\begin{array}{c}44.9 \\
41\end{array}$ & 300 & $\begin{array}{l}\text { Tidak } \\
\text { sesuai }\end{array}$ \\
\hline $\begin{array}{l}3 \\
3\end{array}$ & $\begin{array}{l}\text { AKASH } \\
\text { A } \\
\text { BEIGE }\end{array}$ & 150 & $\begin{array}{c}435 \\
00\end{array}$ & 175 & $\begin{array}{c}44.9 \\
41\end{array}$ & 170 & sesuai \\
\hline $\begin{array}{l}3 \\
4 \\
\end{array}$ & $\begin{array}{l}\text { AKASH } \\
\text { A } \\
\text { GREY }\end{array}$ & 150 & $\begin{array}{c}435 \\
00\end{array}$ & 175 & $\begin{array}{c}44.9 \\
41\end{array}$ & 100 & $\begin{array}{l}\text { Tidak } \\
\text { sesuai }\end{array}$ \\
\hline
\end{tabular}

\section{Pembahasan}

Berdasarkan hasil pengujian data keramik diatas, maka implementasi algoritma $K$-Means untuk pengujian data bulan November dengan Desember untuk perkiraan stok barang yang akan datang dan harga untuk konsumen tidak sepenuhnya bisa memberikan hasil perkiraan yang tepat. Sedangkan untuk data pelanggan, dapat diperoleh informasi mengenai pelanggan yang potensial untuk dapat dipertahankan sebagai pelanggan tetap.

\section{SIMPULAN}

Dari hasil penelitian, dapat disimpulkan bahwa untuk memperoleh hasil pengujian dengan mengimplementasikan algoritma $K$ Means sebaiknya menggunakan pengujian data lebih banyak dengan membandingkan data setiap periode bulan serta dapat menggunakan atribut data lainnya sehingga hasil pengujian akan memberikan hasil yang lebih baik. Penggunaan algoritma $K$ Means, sangat tergantung pada hasil pusat cluster dimana hasil cluster juga dipengaruhi dari nilai centroid awal yang dimasukkan, atribut data dan jumlah data yang digunakan, perbedaan pengambilan data pusat centroid awal juga mempengaruhi hasil akhir centroid.

\section{DAFTAR PUSTAKA}

[1] Astuti, W. 2015. Clustering Program Keahlian Pada Pendaftaran Siswa Baru (PSB) Dengan Menggunakan Algoritma K-Means: Studi Kasus Di SMKN 1 Nguling. ISSN: 2085 - 3092

[2] Kusrini, Lutfi dan Emha Taufiq. 2009. Algoritma Data Mining. Yogyakarta:Penerbit Andi.

[3] Muningsih, Elly dan Sri Kiswati. 2015. Penerapan Metode K-Means Untuk Clustering Produk Online Shop Dalam Penentuan Stok Barang. Yogyakarta: AMIK BSI. ISSN: 2338-9761

[4] Santoso, Yessica P. Marlina. Agung, H. 2018. Implementasi Metode $K$ Means Clustering pada Sistem Rekomendasi Dosen Tetap Berdasarkan Penilaian Dosen. Banten: Universitas Pamulang. ISSN: 25411004

[5] Ong, Oscar J. 2013. Implementasi Algoritma K-Means Clustering Untuk Menentukan Strategi Marketing President University. Bekasi: Universitas Presiden. ISSN: 1412-6869

[6] Santosa, B. 2007. Data Mining: Teknik Pemanfaatan Data untuk Keperluan Bisnis, Graha Ilmu, Yogyakarta.

[7] Santoso, S. 2010. Statistik Multivariat. Jakarta: Elex Media Komputindo.

[8] Sulianta, Feri. 2014. Customer Profiling Pada Supermarket Menggunakan Algoritma K-Means Dalam Memilih Produk Berdasarkan Selera Konsumen Dengan Daya Beli Maksimum. Universitas Widyatama. ISSN : 2407-3911. 